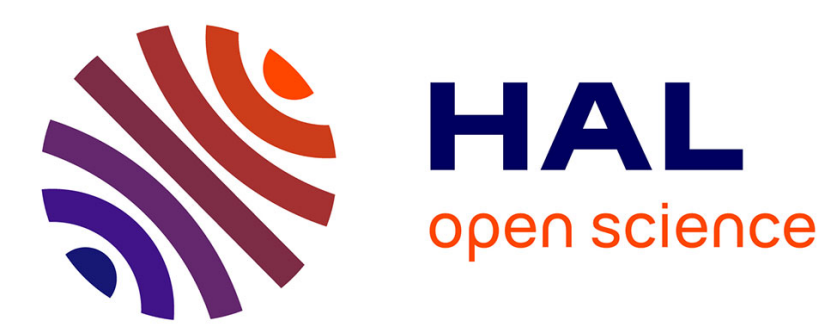

\title{
Dynamic interactions between the gulf of Guinea passive margin and the Congo River drainage basin. Part 1 : Morphology and mass balance
}

Pascale Leturmy, F. Lucazeau, F. Brigaud

\section{- To cite this version:}

Pascale Leturmy, F. Lucazeau, F. Brigaud. Dynamic interactions between the gulf of Guinea passive margin and the Congo River drainage basin. Part 1: Morphology and mass balance. Journal of Geophysical Research, 2003, 108 (B8), 2383, pp.1-13. 10.1029/2002JB001927 . hal-00067784

\section{HAL Id: hal-00067784 \\ https://hal.science/hal-00067784}

Submitted on 29 Jan 2021

HAL is a multi-disciplinary open access archive for the deposit and dissemination of scientific research documents, whether they are published or not. The documents may come from teaching and research institutions in France or abroad, or from public or private research centers.
L'archive ouverte pluridisciplinaire HAL, est destinée au dépôt et à la diffusion de documents scientifiques de niveau recherche, publiés ou non, émanant des établissements d'enseignement et de recherche français ou étrangers, des laboratoires publics ou privés. 


\title{
Dynamic interactions between the gulf of Guinea passive margin and the Congo River drainage basin: 1. Morphology and mass balance
}

\author{
Pascale Leturmy \\ Département des Sciences de la Terre, Université de Cergy-Pontoise, Cergy-Pontoise, France
}

Francis Lucazeau

Laboratoire Géosciences Marines, Institut de Physique du Globe de Paris, Paris, France

Frédéric Brigaud

Total E\&P Norge AS, Stavanger, Norway

Received 15 April 2002; revised 5 December 2002; accepted 12 February 2003; published 16 August 2003.

[1] A sediment budget between the Congo River drainage basin and the western African margin in the Gulf of Guinea is proposed on the basis of published and unpublished offshore Tertiary isopach maps, and onshore digital elevation analysis. The overall denudation of that area may be as high as $3.5 \times 10^{6} \mathrm{~km}^{3}$ with a maximum of $10 \%$ coming from Mesozoic and Cenozoic covers. The southern part of the Congo River basin, related to uplift of the South African and Kalahari shields, appears as the most immature from the morphologic standpoint but provides one third of the present-day sediment production; it represents a maximum denudation of $150,000 \mathrm{~km}^{3}$. On the easternmost part, East African Rift drainage basins show a more mature relief and a maximum denudation of $270,000 \mathrm{~km}^{3}$, which can increase to $570,000 \mathrm{~km}^{3}$ if the Congo drainage basin had extended up to the east branch of the rift. These values are confidently established from the existence of remnant geological surfaces, and can explain the volume of Tertiary sediment in the Gulf of Guinea. During upper Cretaceous, the most important accumulations of sediments correspond to the Ogooe and Kwanza fans, which shows that the organization of continental drainage was different as was potential source of sediments. In the northern part of the present-day Congo River drainage basin, there was a compressional episode during Santonian that may have caused significant relief and erosion along a Benue-Chad axis. INDEX TERMS: 8105 Tectonophysics: Continental margins and sedimentary basins (1212); 8110 Tectonophysics: Continental tectonics_-general (0905); 8124 Tectonophysics: Earth's interior-composition and state (1212); 8155 Tectonophysics: Plate motions - general; 9305 Information Related to Geographic Region: Africa; KEYWORDS: denudation, mass balance, morphology, relief, uplift, Africa

Citation: Leturmy, P., F. Lucazeau, and F. Brigaud, Dynamic interactions between the gulf of Guinea passive margin and the Congo River drainage basin: 1. Morphology and mass balance, J. Geophys. Res., 108(B8), 2383, doi:10.1029/2002JB001927, 2003.

\section{Introduction}

[2] The sediment deposits of continental margins are records of Earth surface erosion and drainage processes; sediment budgets between source and deposition areas provide a first-order understanding of the drainage basin dynamics at geological timescales [e.g., Rust and Summerfield, 1990; Métivier et al., 1999]. In most cases, high denudation rates as well as large Tertiary fans are related to active tectonics in the major orogenic domains (Himalayas, Andes, Alps, Taiwan, New Zealand), and characteristic of high elevation drainage basins [Milliman and Syvitski, 1992]; $80 \%$ of the Amazon load comes, for instance, from the active Andean chain that represents

Copyright 2003 by the American Geophysical Union. 0148-0227/03/2002JB001927\$09.00
$10 \%$ only of the drainage area [Meade et al., 1985]. On the other hand, climatic conditions (rainfall, runoff, etc.) do not display a clear correlation with present-day solid loads of large river systems [Pinet and Souriau, 1988].

[3] The African margins, especially Gulf of Guinea in offshore Gabon-Angola, have large Tertiary accumulations with regard to the lack of significant tectonic activity since the Pan African orogeny $(\sim 600 \mathrm{Ma})$. The present-day Congo River delivery is also one of the smallest observed for large rivers [Pinet and Souriau, 1988; Milliman and Syvitski, 1992], but the Congo fan extends up to $1000 \mathrm{~km}$ from the coastline [Savoye et al., 2000]. It is therefore important to understand whether or not these large volumes of sediments are compatible with erosion in the Congo drainage basin over a certain period of time. As relics of geological surfaces exist within the Congo River drainage 


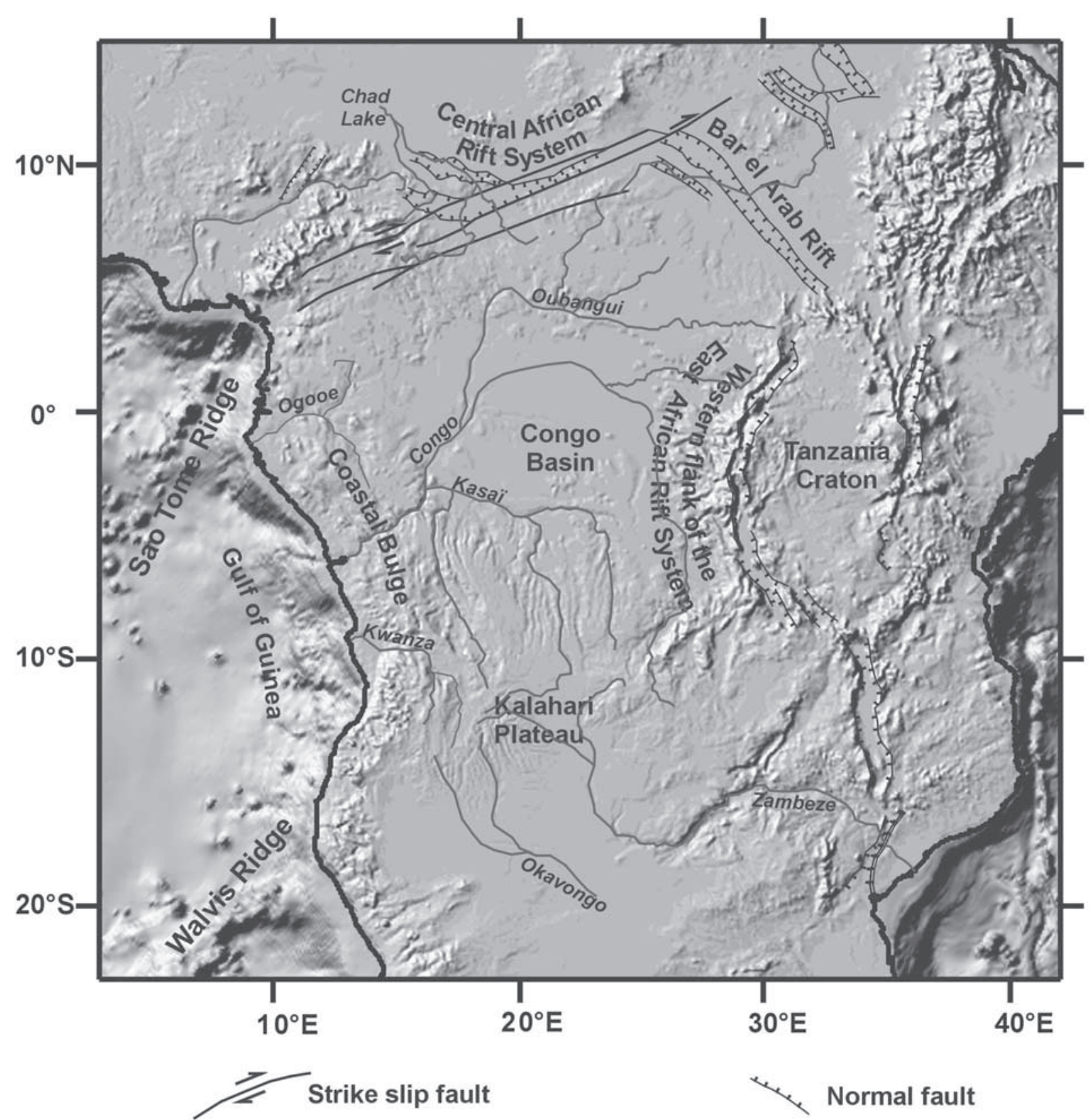

Figure 1. Shaded relief and tectonic provinces in the studied area. The Congo River drainage basin is surrounded by topographic highs which limit the extension of drainage. It is bordered to the north and northwest by Central African Rift System and Bar el Arab Rift of Jurassic age, to the east by East African Rift System of Tertiary age and to the south by Kalahari Plateau. Offshore, gulf of Guinea margin is a domain limited by two topographic ridges (Sao Tome ridge to the north and Walvis Ridge to the south) which protect sediments from dispersion.

basin and as oil exploration research can provide a quantitative view of sediment fluxes, a mass balance analysis is possible. The Gabon to Angola domain is limited by two topographic volcanic ridges, Sao Tome Ridge on the northern part and Walvis Ridge on the southern part; both protect the sediment deposits from important dispersion by submarine currents and relate these deposits to a unique large drainage basin, making the system almost closed (Figure 1).

[4] In this paper, we develop a quantitative analysis of the sediment budget and erosion process for the Congo River drainage basin/Gulf of Guinea margin. Offshore volumetric estimates are derived from published and unpublished isopach maps and corrected for dissolved loads, whereas onshore volumetric estimates and chronology of erosion are obtained from the analysis of the GTOPO30 topographic database and geological map of Africa.

\section{Regional Context}

\subsection{Offshore}

[5] The studied area includes the Gulf of Guinea, between Gabon and Angola, and the drainage basins delivering 


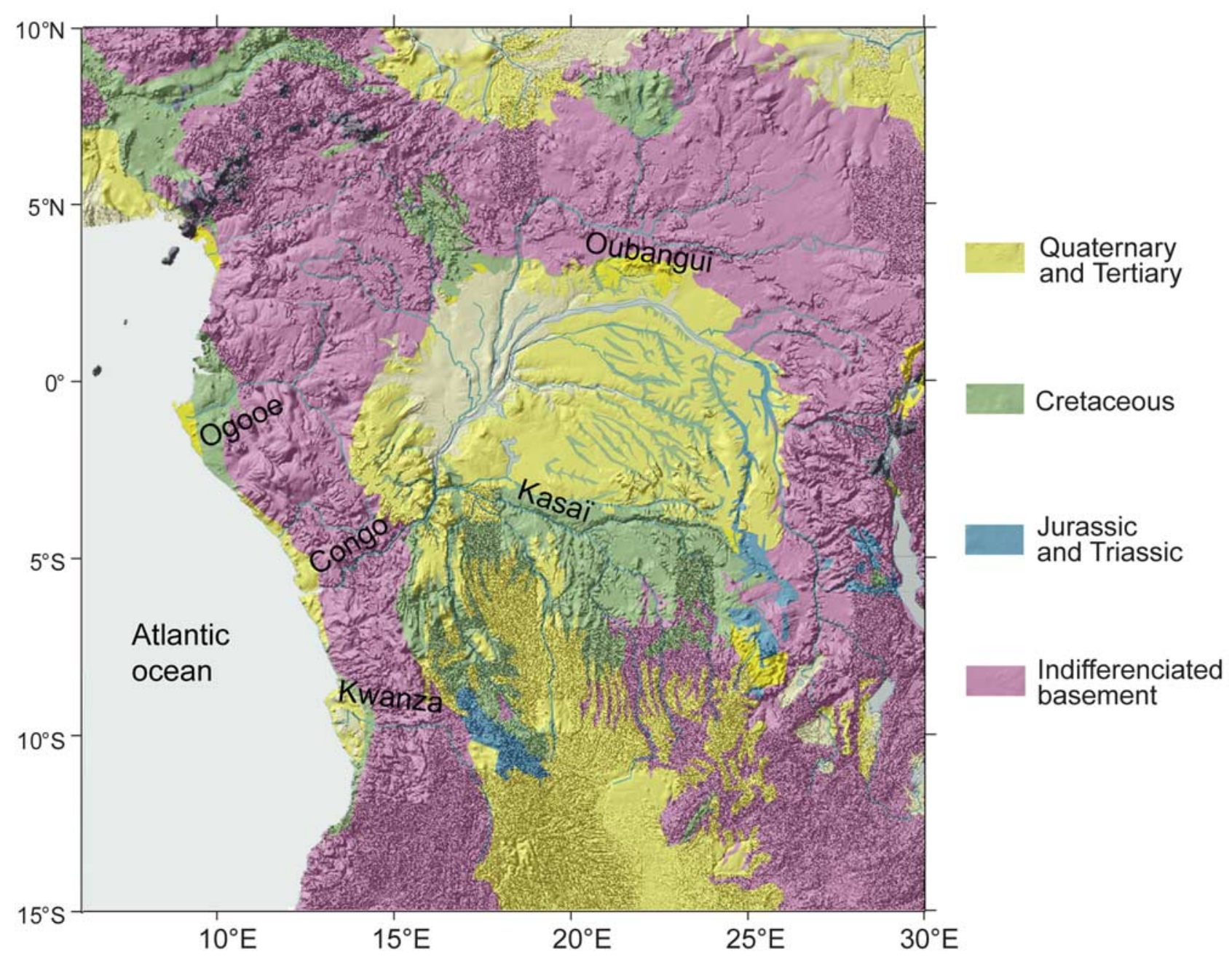

Figure 2. Regional geology projected on GTOPO30 digital elevation model. Major topographic highs surrounding the Congo River drainage basin are mainly basement rocks, whereas central Congo basin is a subsiding sedimentary zone.

sediments to that part of the margin. It covers $5 \times 10^{6} \mathrm{~km}^{2}$ onshore and $2 \times 10^{6} \mathrm{~km}^{2}$ offshore.

[6] Breakup of Gondwana during Early Cretaceous has separated this area from Brazil. Rifting propagates from south to north, beginning at $126.5 \mathrm{Ma}$ south of the Walvis ridge and at 118.7 Ma in the Benue Trough [Nürnberg and Mueller, 1991]. It ends up in late Aptian with a marine transgression which generates salt deposit along all the Gabon-Angola margin.

[7] South of this domain (Congo-Angola), postrift sedimentation begins with the development of a shallow water carbonate platform during Albian. Carbonates are progressively replaced by more detritic sediments as the margin subsides. At the Eocene-Oligocene transition, submarine erosion affects the upper slope and the shelf break of the West African margin and may have removed up to $1000 \mathrm{~m}$ of sediments [Lavier et al., 2001]. In the north (Gabon), a late Cretaceous sedimentary succession of estuarine-deltaic mud and sands are followed by a carbonate sedimentation [Séranne et al., 1992; Rasmussen, 1996].

[8] Postrift sediments are characterized in that part of the African margin by raft tectonics related to salt decollements [Burollet, 1975; Ludin, 1992; Mauduit and Brun, 1998;
Valle et al., 2001]. Valle et al. [2001] recognize three main periods for this deformation (Aptian; late Eocene-late Oligocene and late Miocene-recent).

\subsection{Onshore}

[9] The Congo basin is a spread drainage basin $(3.5 \times$ $10^{6}$ of $\mathrm{km}^{2}$ ) that takes place above a circular Paleozoic sedimentary basin; it remained almost continuously subsiding before Tertiary and has been filled with lacustrine, marine and continental sediments through time [Lawrence and Makazu, 1988]. The central part of the basin is flat: a preserved surface at $610 \mathrm{~m}$ covers up to $330,000 \mathrm{~km}^{2}$. Divides of the Congo River drainage basin are related to various geological structures. On the western part of the Congo River drainage basin, Precambrian igneous and metamorphic outcrops [Brognon, 1971] are exposed within a $500-800 \mathrm{~m}$ high topographic bulge (Figure 2). As the Mesozoic and Cenozoic covers are tilted seaward on the proximal margin and affected by several erosion unconformities [Emery et al., 1975], it is likely that the origin of the bulge is recent. In the northern part of the Congo basin, the Central African Rift System is active from late Jurassic to Early Cretaceous [Genik, 1992; Guiraud and Bosworth, 


\section{A: Syn-rift sediments}
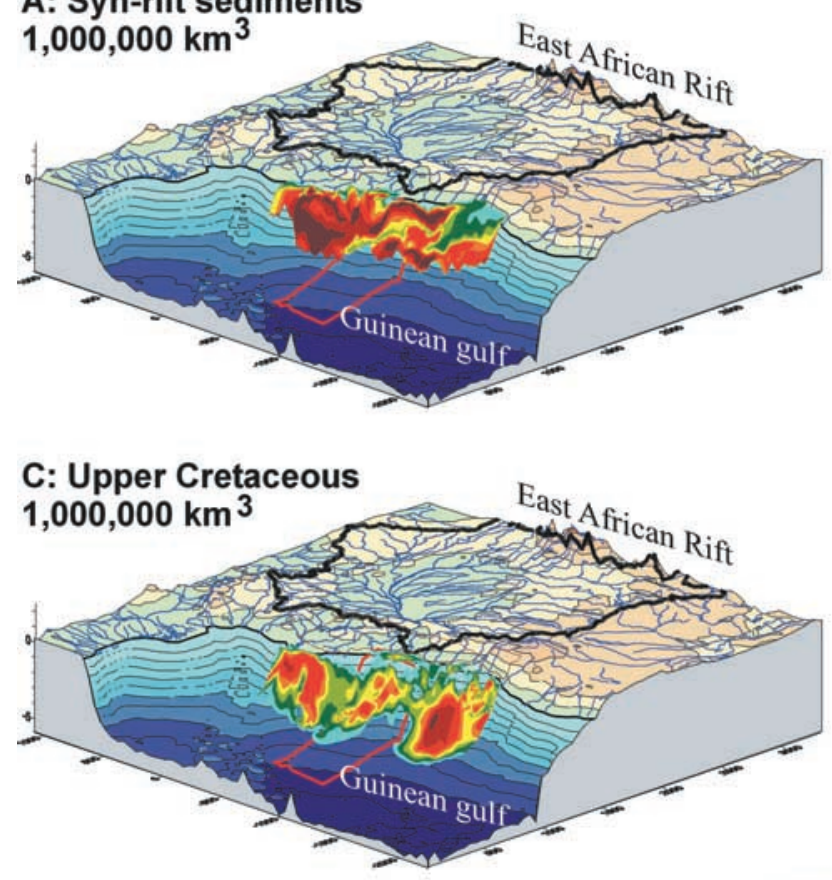
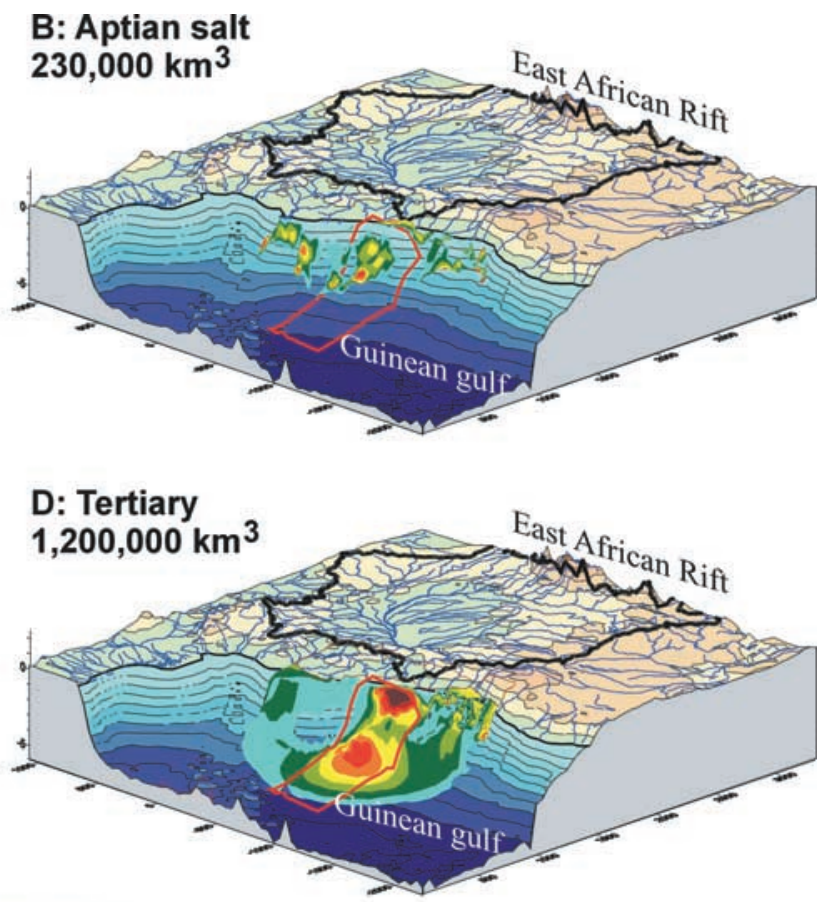

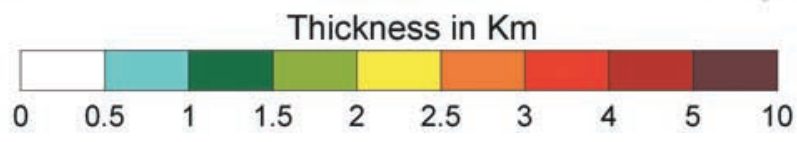

Figure 3. Evolution of sediment accumulation along the West African margin since break up of Gondwanaland. Red rectangle corresponds to the area investigated by Zaiango experiment [Savoye et al., 2000], and heavy black line inland corresponds to the limit of the Congo River drainage basin. (a) Synrift sedimentation and (b) Aptian salt represent approximately one third of the total amount of sedimentation. (c) During upper Cretaceous, two main depot centers are individualized offshore and correspond to the present-day Ogooe River outlet in the north and Kwanza River outlet in the south. (d) During Tertiary, one third of the total amount of sediments is deposited in the Congo River fan. Migration of depot centers from Upper Cretaceous to Tertiary is supposed to be related to a major change in drainage organization inland.

1997] and has been inverted later on during Santonian as were all extensional basins in Africa [Guiraud and Bosworth, 1997]. The Central African Rift still appears as a $900 \mathrm{~m}$ maximum elevation relief and the presence of Lower Cretaceous deposits on its southern flank (Figure 2) suggests that it has never been as high as the East African Rift. On the eastern part of the Congo basin, East African Rift is a morphological barrier since Middle Miocene at least, presently as high as $3400 \mathrm{~m}$. On the southern part of the Congo basin, the Kalahari plateau appears as a relatively flat area with a mean elevation of $1000 \mathrm{~m}$, but the age of this topography has not clearly been established. Large-scale vertical motions [Sahagian, 1988; Nyblade and Robinson, 1994] and seismic tomography [Lithgow-Bertelloni and Silver, 1998] suggest that this topography could be supported dynamically in the deep mantle.

[10] Drainage system as it appears now is obviously a recent feature that develops during Tertiary, as a consequence of the progressive uplift of the present divides.

\section{Estimation of Tertiary Denudation From Sediment Accumulation}

[11] Large-scale studies of the Atlantic margins [Emery et $a l ., 1975]$ have shown the deep offshore extension of the
Congo fan and Tertiary deposits in the Gulf of Guinea, but had low stratigraphic and spatial resolutions. Oil exploration studies have substantially increased the knowledge of sediment distribution in the deep offshore of the Gulf of Guinea by $2 \mathrm{D}$ and $3 \mathrm{D}$ seismic investigations. It has resulted in new geological and geophysical interpretations on the continental margin and the transition to the oceanic domain [e.g., Marton et al., 2000; Uenzelmann-Neben, 1998; Lavier et al., 2001]. However, the exploration domain investigated by commercial seismic studies ends up in the vicinity of ocean-continent boundary, where more or less 3000-4000 m of sediment still exist. A remaining uncertainty on the total amount of Tertiary comes therefore from estimates of the sediment wedge on the oceanic crust, only constrained by a limited number of long enough profiles [Emery et al., 1975; Savoye et al., 2000]. Our global estimate of postrift sediment, including the distal sedimentary wedge, is $3.5 \pm 1 \times 10^{6} \mathrm{~km}^{3}$.

[12] The compilation of sedimentation data is presented as a set of time sliced isopach maps (Figure 3) that show the displacement of depot centers with time and as sedimentation rates across the Congo fan (Figure 4) that provide a detailed time evolution. Synrift sediments and Aptian salt (Figures $3 \mathrm{a}$ and $3 \mathrm{~b}$ ) represent one third of the total amount of sediments $\left(1,000,000 \mathrm{~km}^{3}\right.$ and $270,000 \mathrm{~km}^{3}$, respectively); a north-south gradient appears in the synrift 


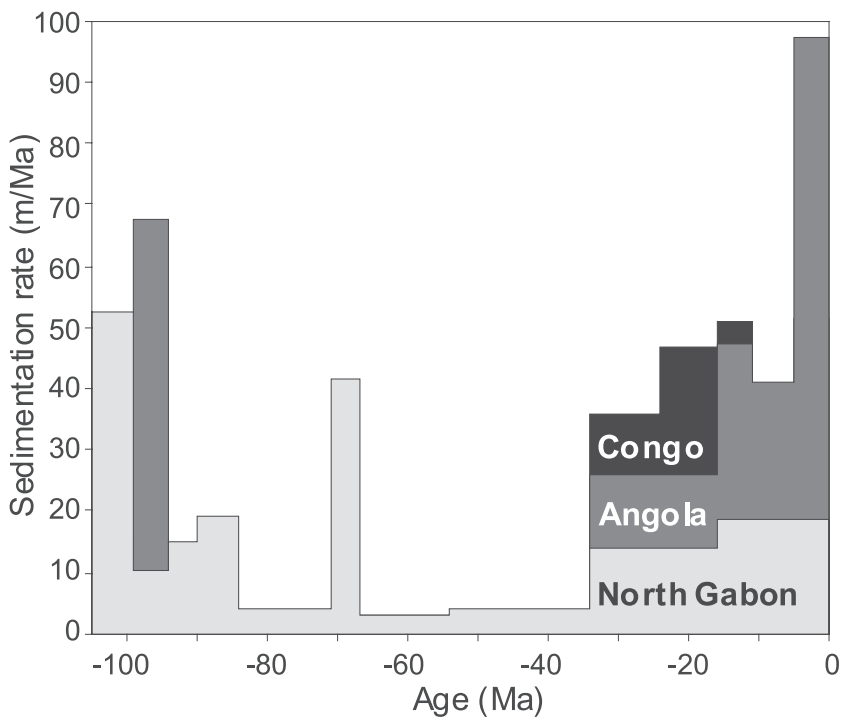

Figure 4. Average sedimentation rates across three sections in gulf of Guinea. All curves show a similar trend: rifting and uplift of flanks causes synrift erosion and sedimentation (140-90 Ma). This period is followed by slow sedimentation rates during upper Cretaceous and lower Tertiary (locally higher in Ogooe and Kwanza vicinity). From $34 \mathrm{Ma}$ to present-day, sedimentation rates progressively increase up to values as high as $100 \mathrm{~m} / \mathrm{Myr}$ in Congo fan.

sedimentation but may be partly related to some imaging problem. During Upper Cretaceous (Figure 3c), the volume estimate of sediment is $1 \times 10^{6} \mathrm{~km}^{3}$. Two major depot centers as thick as $5 \mathrm{~km}$ are individualized and correspond to the present-day Ogooe River in the north and Kwanza River in the south. On the other hand, the present-day Congo River has a smaller contribution, which probably reflect a smaller drainage basin at that time. During Tertiary, the total amount of accumulation is $1.2 \mathrm{~km}^{3}$ (Figure $3 \mathrm{~d}$ ), but the depot center is now restricted to the Congo fan where thickness reaches $6 \mathrm{~km}$ in the proximal part of the fan and $4 \mathrm{~km}$ in the distal part. This indicates that a complete change in drainage system happened at that time. A detailed analysis of the sediment rate evolution with time (Figure 4) clearly shows that the sedimentation rates before Oligocene have been low or reduced by erosion in the proximal part of the margin [Séranne et al., 1992; McGinnis et al., 1993; Lavier et al., 2001]. When the modern drainage of Congo River takes place at about $34 \mathrm{Ma}$, the sedimentation rate increases almost continuously with time (Figure 4), in connection with either an elevation of the continent or the effect of the switch from greenhouse to icehouse conditions [Séranne, 1999]. This point will be discussed later on and in our companion paper [Lucazeau et al., 2003].

[13] In addition to the offshore sediment volume, the alluvial plain of Congo River stores a significant Mesozoic/Tertiary cover that may reach up to $1 \mathrm{~s}$ two-way travel time [Lawrence and Makazu, 1988]. Expanding a corresponding average thickness of $500 \mathrm{~m}$ over the alluvial plain area $\left(1 \times 10^{6} \mathrm{~km}^{2}\right)$ may lead to an additional $0.5 \times 10^{6} \mathrm{~km}^{3}$. On the other hand, present-day dissolved load of the Congo River can represent from $60 \%$ of the solid load [Gaillardet et al., 1995] to $100 \%$ [Pinet and Souriau, 1988]. The proportion of dissolved material that has not been precipitated in the Gulf of Guinea and returned to the global ocean is difficult to estimate, and this can also lead to an underestimation of the volume of erosion. The total volume of erosion material provided to the Gulf of Guinea may be therefore of the order of $5 \times 10^{6} \mathrm{~km}^{3}$ after the breakup of Gondwana, and up to $1.5 \times 10^{6} \mathrm{~km}^{3}$ during Tertiary.

\section{Estimation of Tertiary Denudation From Relic Surfaces}

[14] Previous estimates of denudation have been obtained along the East African Rift and in Namibia by restorations of the cooling history inferred from Apatite Fission Track Analysis (AFTA). Van der Beek et al. [1998] observed three cooling events along the Malawi and Rukwa Rift flank at $250 \mathrm{Ma}$, around $150 \mathrm{Ma}$, and after 40-50 Ma with less than $1 \mathrm{~km}$ of denudation associated with this last event. Foster and Gleadow [1996] proposed similar results for the Kenya rift, with three stages of denudation at $220 \mathrm{Ma}, 140-120 \mathrm{Ma}$ and 60-70 Ma with $2.5 \mathrm{~km}$ denudation for the latest stage. In Tanzania, Noble et al. [1997] proposed two stages of cooling at 110 and $65 \mathrm{Ma}$. Conversely, van den Haute [1984] results suggest a slower and more continuous cooling since 300-400 $\mathrm{Ma}$ in Rwanda and Burundi, with a mean denudation rate between 2 and $10 \mathrm{~m} / \mathrm{Myr}$. In Namibia, most of denudation follows the Atlantic breakup (120 Ma) on the coastal domain, and increases inland during Tertiary [Gallagher and Brown, 1999]. All of these results indicate that a stage of denudation has been driven by the South Atlantic rifting, and another one started from early Tertiary (around $50 \mathrm{Ma}$ ). In the central rift of Kenya, Roessner and Strecker [1997] reconstructed a paleosurface from relics of 3.4 Ma basalts to infer the volume that has been eroded between this surface and the present-day topography. They obtain a denudation rate in the range of $11-14 \mathrm{~m} / \mathrm{Myr}$. At a different timescale and a different space scale, other estimates of denudation can be derived from geochemical budget [Gaillardet et al., 1995]; an average denudation rate of $6 \mathrm{~m} / \mathrm{Myr}$ is obtained for the overall Congo basin, with a greater contribution from Eastern and Southern tributaries.

[15] In order to estimate the regional variation of denudation in the Congo River basin, we have generalized the technique of paleosurface reconstructions similar to that developed by Roessner and Strecker [1997]. Topography is obtained from the GTOPO30 database [U.S. Geological Survey, Earth Resources Data Center (USGS-EDC), 1996], relics surfaces are respectively defined by the envelope of topographic ridges, base of Tertiary/Quaternary, base of Cretaceous, base of Triassic/Jurassic (Figure 5); these three geological limits are picked up on the 1/1,000,000 geological map draped over GTOPO30 topography (Figure 2). Subtraction of the present topography from those envelopes can give a first-order estimate of the eroded volume of rocks. Where geological relics are missing, extrapolation of the average thickness for a given geological unit has been used to maximize estimation of denudation. For instance, Cretaceous unit is well constrained along the western part of the Kasai subbasin, where the mean thickness is $130 \mathrm{~m}$. This thickness value is used where Cretaceous has not been preserved along the coast and along the northwest flank of the rift. 

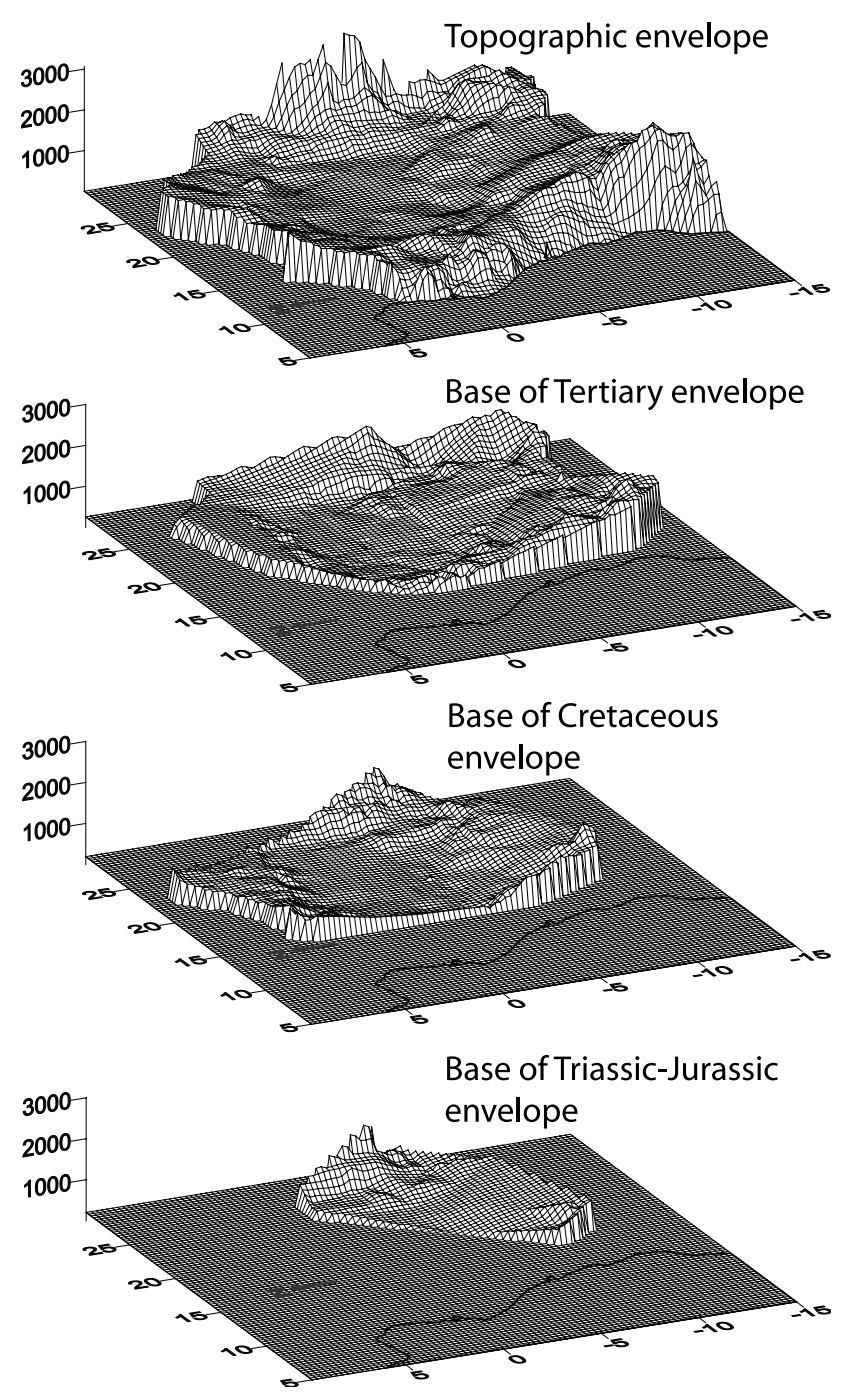

Figure 5. Relic surfaces reconstructed from GTOPO30 DEM and geological map. Topographic envelope is a smooth surface matching a selection of highest elevation pixels. Base of Tertiary, base of Cretaceous and base of Triassic-Jurassic envelopes are surfaces constructed with preserved outcrops picked up on geological map. Volumes between these different surfaces have been used to estimate erosion linked to the Congo River drainage basin.

[16] Accordingly, denudation below the envelope of topographic ridges ranges between $725,000 \mathrm{~km}^{3}$ to $1,000,000 \mathrm{~km}^{3}$ whether or not this extrapolation of the average thickness has been used. This represents 300,000 to $400,000 \mathrm{~km}^{3}$ of Cenozoic, 75,000 to $275,000 \mathrm{~km}^{3}$ of Mesozoic and $350,000 \mathrm{~km}^{3}$ of basement (Figure 6). The principal sources of sediments are the East African Rift $\left(200,000-270,000 \mathrm{~km}^{3}\right.$ in volume or $230-320 \mathrm{~m}$ average denudation) and the Kasai domain (140,000-150,000 $\mathrm{km}^{3}$ or $160-175 \mathrm{~m}$ average denudation). Coastal drainage basins deliver large denudation as well: Ogooe drainage basin in the northwest corresponds to $45,000-85,000 \mathrm{~km}^{3}$ (190-385 m average denudation) whereas Kwanza drainage basin in southwest to $36,000-50,000 \mathrm{~km}^{3}(210-300 \mathrm{~m}$ average denudation).

\section{Digital Elevation Analysis}

[17] Previous analysis provides volumetric estimates of denudation in the different geological structures of the Congo drainage basin, but no real information on the
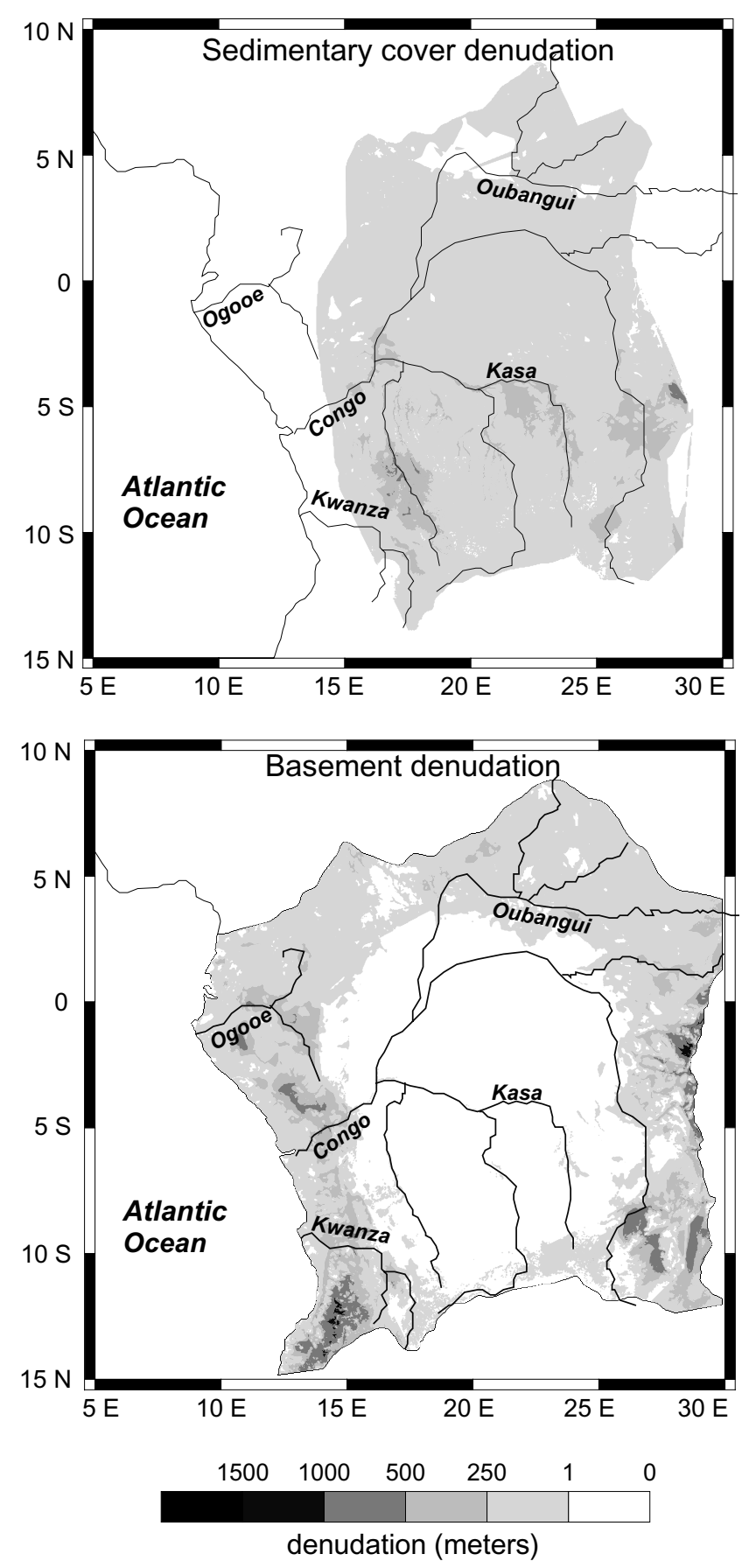

Figure 6. Distribution of estimated erosion thickness. (a) The overall sediment cover denudation represents 375,000 to $675,000 \mathrm{~km}^{3}$, including $300,000-400,000 \mathrm{~km}^{3}$ of Tertiary, $75,000-275,000 \mathrm{~km}^{3}$ of Cretaceous and $14,000 \mathrm{~km}^{3}$ of Trias-Jurassic. (b) The minimum denudation of basement represents $350,000 \mathrm{~km}^{3}$. Total amount of denudation in this area ranges between $725,000 \mathrm{~km}^{3}$ and $1,000,000 \mathrm{~km}^{3}$, only one third of the total volume of sediments deposited offshore. 


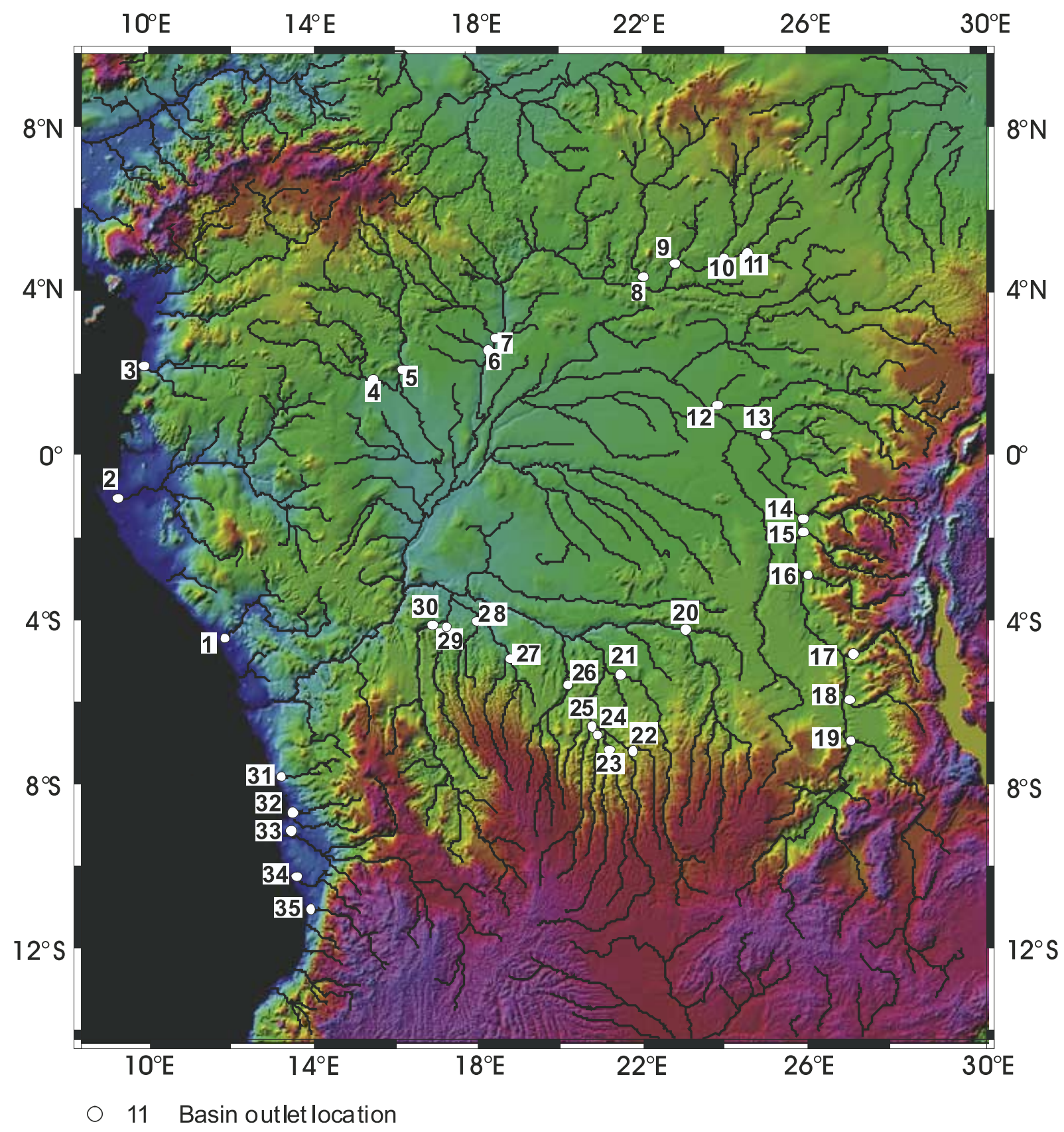

Figure 7. Location of studied drainage basin outlets in hypsometric and relief length scale analysis. Numbers refer to Table 1.

chronology of denudation. We examine here if some morphologic features can provide such information.

\subsection{Characteristics of Drainage Basins}

[18] We used the GTOPO30 database [USGS-EDC, 1996] at the resolution of $30 \mathrm{arc} \mathrm{sec}$. Several morphologic analyses have used large-scale databases to characterize morphologic properties of topography [Weissel et al., 1994; van der Beek and Braun, 1998; Lucazeau and Hurtrez, 1997; Vörösmarty et al., 2001]. We have selected 35 drainage basins related to the Gulf of Guinea (Figure 7 and Table 1), including 27 tributaries of the Congo River and 8 coastal rivers located between $3^{\circ} \mathrm{N}$ and $12^{\circ} \mathrm{S}$. The 27 tributaries have been taken in the upstream parts of the Congo River and their outlets chosen in similar conditions of channel slope; their cumulated drainage area represents $60 \%$ of the Congo drainage basin while the $40 \%$ remaining corresponds mostly to the inner part where sediment storage occurs. Drainage basins areas range from $12,000 \mathrm{~km}^{2}$ to $220,000 \mathrm{~km}^{2}$. The morphometric analysis may be influenced by the differences of upstream drainage areas [Ohmori, 1993; Lifton and Chase, 1992; Hurtrez et al., 1999b], but the choice of outlets in comparable positions with respect to the Congo sedimentary basin seems to have minimized this effect; elevation of the outlets ranges from $515 \mathrm{~m}$ for the easternmost drainage basins and $265 \mathrm{~m}$ for the westernmost drainage basins.

[19] Channel networks and drainage basins have been extracted with MAD software [Moussa, 1991; Moussa et 
Table 1. Morphometric Properties of the 35 Drainage Basins of the Studied Area

\begin{tabular}{|c|c|c|c|c|}
\hline No. $^{a}$ & River & $\begin{array}{l}\text { Drainage } \\
\text { Area, } \mathrm{km}^{2}\end{array}$ & $\begin{array}{c}\text { Hypsometric } \\
\text { Integral }\end{array}$ & $\begin{array}{c}\text { Hurst } \\
\text { Exponent }\end{array}$ \\
\hline 1 & Kouilou & 62,500 & 0.49 & 0.65 \\
\hline 2 & Ogooe & 139,400 & 0.43 & 0.67 \\
\hline 3 & NTem & 39,900 & 0.54 & 0.68 \\
\hline 4 & Sangha Dja & 70,100 & 0.26 & 0.55 \\
\hline 5 & Sangha Kadei & 83,500 & 0.39 & 0.59 \\
\hline 6 & Ibenga & 30,200 & 0.45 & 0.58 \\
\hline 7 & Lobaye & 25,200 & 0.33 & 1.08 \\
\hline 8 & Kotto & 46,600 & 0.42 & 0.5 \\
\hline 9 & M'Bari & 79,200 & 0.54 & 0.49 \\
\hline 10 & Chinko & 24,800 & 0.38 & 0.6 \\
\hline 11 & Ouara & 53,300 & 0.64 & 0.34 \\
\hline 12 & Aruwimi & 111,900 & 0.27 & 0.67 \\
\hline 13 & Lindi & 88,200 & 0.14 & 0.73 \\
\hline 14 & Lowa & 52,250 & 0.22 & 0.62 \\
\hline 15 & Ulindi & 28,900 & 0.21 & 0.71 \\
\hline 16 & Elila & 27,000 & 0.23 & 0.61 \\
\hline 17 & Luama & 25,000 & 0.21 & 0.59 \\
\hline 18 & Lukuga & 21,400 & 0.28 & 0.38 \\
\hline 19 & Luvua & 38,900 & 0.27 & 0.45 \\
\hline 20 & Sankuru & 116,200 & 0.51 & 0.37 \\
\hline 21 & Lulua & 70,300 & 0.52 & 0.23 \\
\hline 22 & Kasaï & 60,000 & 0.51 & 0.40 \\
\hline 23 & Luembe & 41,900 & 0.50 & 0.20 \\
\hline 24 & Luachimo & 19,700 & 0.54 & 0.27 \\
\hline 25 & Chicapa & 21,000 & 0.45 & 0.30 \\
\hline 26 & Lowange & 53,700 & 0.47 & 0.40 \\
\hline 27 & Kwenge & 20,600 & 0.47 & 0.31 \\
\hline 28 & Inzia & 22,200 & 0.39 & 0.20 \\
\hline 29 & Wamba & 33,600 & 0.39 & 0.29 \\
\hline 30 & Kwango & 139,000 & 0.44 & 0.40 \\
\hline 31 & M'Bridge & 77,300 & 0.48 & 0.61 \\
\hline 32 & Dange & 26,800 & 0.57 & 0.68 \\
\hline 33 & Kwanza & 220,750 & 0.46 & 0.47 \\
\hline 34 & Longa & 19,500 & 0.40 & not available \\
\hline 35 & Queve & 21,400 & 0.47 & 0.39 \\
\hline
\end{tabular}

${ }^{\mathrm{a}}$ Numbers refer to Figure 7.

al., 1999], based on the standard methods described by Band [1986]. It determines the downward steepest slope for each cell to attribute them a flowing direction, and then fills hollows to assure the continuity of drainage. The drainage basin is defined as the set of cells flowing toward a given outlet.

\subsection{Morphometric Parameters}

[20] We retained three morphometric parameters: (1) river longitudinal profile, (2) hypsometry, and (3) relief.

\subsubsection{Longitudinal Profile}

[21] Defined as the longest channel for a given drainage basin, a selection of them is represented in Figure 8. River profile in declining relief has a characteristic concave shape (e.g., Figure 8c). Abrupt local change can be attributed to a tributary junction [Sklar and Dietrich, 1998], a lithologic change or a local tectonic displacement. Rivers are generally very sensitive to vertical tectonic displacements, and they adjust surface warping by deflection, avulsion, erosion and aggradation along the profile or changes in channel pattern [Goodrich, 1898; Howard, 1967; Ouchi, 1985; Merrits et al., 1994; Holbrook and Schumm, 1999]. However, the time response to change in river slope remains difficult to estimate as it depends on rock strength, stream power and magnitude of tectonic movements [Whipple and Tucker, 1999]. Regional studies can provide information on the time response of rivers to tectonic uplift [Hurtrez et al., 1999a], but those results can not be extrapolated to other contexts.

[22] Some characteristic features are observed in the Congo River drainage basin in connection with the local geologic context, whatever the lithology or drainage area considered. Along the East African Rift flank (Figures 8c and $8 \mathrm{~d}$ ), rivers show a typical equilibrium profile in the upstream part, and river slope changes are weak and can be related easily to river junctions or lithologic properties. In the northeastern part of the Congo River drainage basin, rivers show variable patterns: some of them have a typical equilibrium profile (Figure 8e) while others have a flat upstream shape as the Ouara river related to a $610 \mathrm{~m}$ plateau previously described (Figure $8 \mathrm{f}$ ). In the southern (Figures $8 \mathrm{a}$ and $8 \mathrm{~b}$ ) and northwestern (Figure $8 \mathrm{~g}$ ) parts of the Congo River drainage basin, rivers have generally convex profiles with low gradients upstream, typical of retrogressive erosion; in the north, all rivers crossing the coastal bulge are concerned; south of latitude $4^{\circ} \mathrm{S}, 73 \%$ of coastal rivers and all tributaries of Congo River flowing from the Kalahari plateau show this convex profile.

\subsubsection{Hypsometry}

[23] It represents the proportion of basin area below a given elevation [Strahler, 1952]. Hypsometric curve (Figure 9) represents therefore the complete statistics of hypsometry from the divide to the outlet and can be associated with a hypsometric integral value HI. Maturity of drainage basins can be related to shape of hypsometric curves or value of $\mathrm{HI}$; immaturity is characterized by convex curves and high HI value $(\geq 0.65)$ whereas maturity is characterized by S-shaped or concave curves and low HI values $(\leq 0.35)$. Recent studies have pointed out several factors influencing hypsometry: Ohmori [1993] and Masek et al. [1994] proposed that hypsometry is mainly representative of erosional processes; Lifton and Chase [1992] found an influence of tectonics on hypsometric integrals for drainage basins larger than $1000 \mathrm{~km}^{2}$ and a lithologic control on smaller basin hypsometry; Hurtrez and Lucazeau [1999] found similar conclusions.

[24] In the Congo River drainage basin (Figure 9), mature basins are located mostly along the East African Rift flank while immature basins correspond to drainage basins located to the south (Kasaï river, southern coastal rivers) and some basins in the north related to the $610 \mathrm{~m}$ plateau. However, sigmoid to linear curves with various HI $(0.26-0.64)$ are observed in northern drainage basins.

\subsubsection{Relief}

[25] Relief is basically defined as the elevation difference for a given length scale [Anhert, 1970] and has been determined in this study at all scale domains by the technique of structure functions [Weissel et al., 1994; Lucazeau and Hurtrez, 1997]: $\mathrm{R}(\mathrm{l})=\langle|\mathrm{h}(\mathrm{x}+1)-\mathrm{h}(\mathrm{x})|\rangle$, where $\mathrm{h}$ is the elevation, $\mathrm{x}$ the horizontal position, 1 the window length scale and angle brackets refer to the average of all elevation differences in the length scale window 1 . A power law relationship $\mathrm{R}(\mathrm{l})=\mathrm{R}_{0} \mathrm{l}^{\mathrm{H}}$ can describe how relief $\mathrm{R}(\mathrm{l})$ increases with length scale $1 . \mathrm{R}_{0}$ is relief at a reference scale ( $1=10 \mathrm{~km}$ for instance) and $\mathrm{H}$ is the Hurst exponent related to the fractal dimension of topography; Because R(1) is an average value of all couples in the length scale range 1 , 

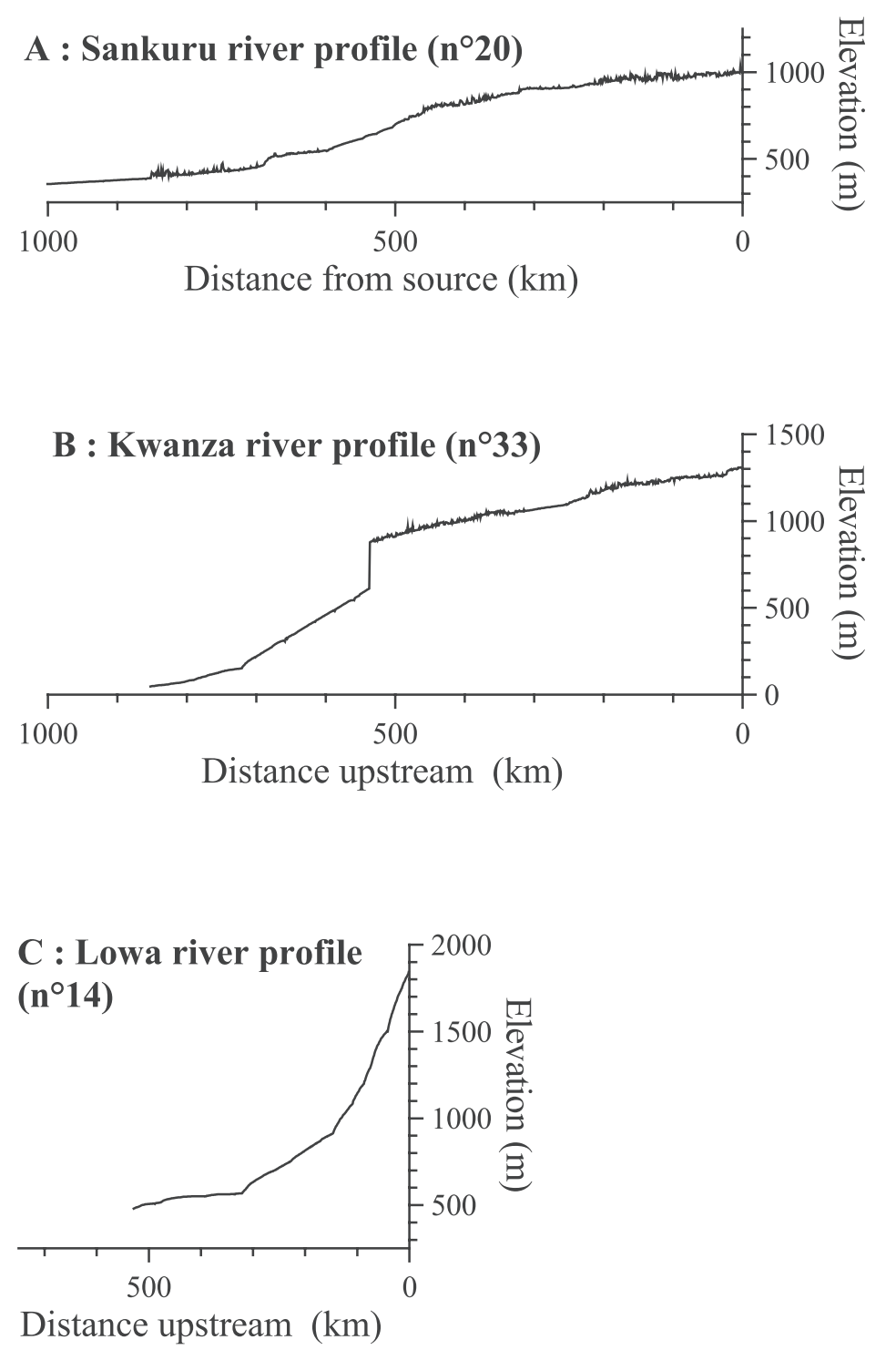
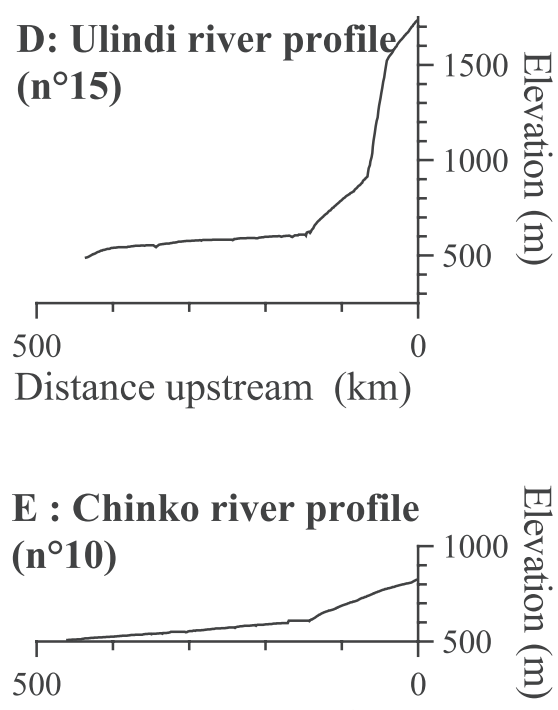

Distance upstream $(\mathrm{km})$

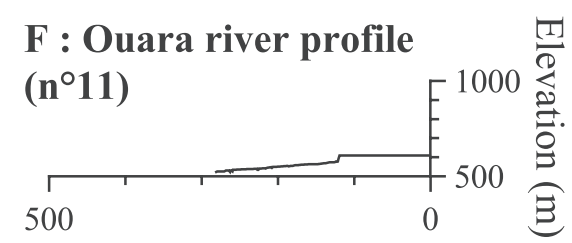

Distance upstream $(\mathrm{km})$

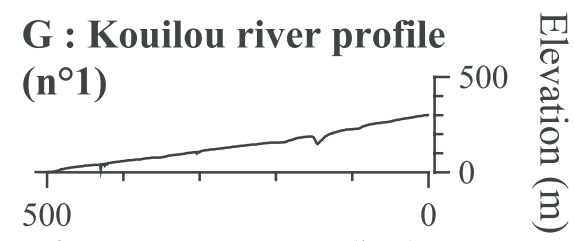

Distance upstream $(\mathrm{km})$

Figure 8. Characteristic river profiles in the studied area. (a and b) Rivers across Kalahari plateau have convex profiles typical of retrogressive erosion. (c and d) River profiles of the Western flank of the East African Rift and (e) of the northern part of the Congo drainage basin have typical equilibrium profiles. (f) Ouara River profile to the north shows an anomalous flat segment upstream linked to a preserved surface $(610 \mathrm{~m})$ in central Congo basin. $(\mathrm{g})$ Rivers crossing coastal bulge have convex profiles.

$\mathrm{H}$ tends to 1 for a smooth topography and $\mathrm{H}$ tends to 0 for a rough topography. Several studies [Weissel et al., 1994; Lucazeau and Hurtrez, 1997; van der Beek and Braun, 1998], proposed that several domains of scales may be identified according to the processes that create topography: diffusive hillslope processes at small scale, river incision at mesoscale and tectonics or geodynamics at large scale. Resolution of GTOPO30 is not good enough to access the small-scale processes and the smooth trend observed at the lower scales in this study (Figure 10) is mostly caused by the interpolation of the DEM. We have considered therefore the mesoscale domain only, as it corresponds to the domain where the amplitude and scaling exponent can provide information on the tectonic and erosion interactions [Lifton and Chase, 1992; Weissel et al., 1995; Hurtrez et al., 1999a].
[26] High Hurst exponents are found in East African Rift $(0.38-0.71)$ and the northern part $(0.5-1.0)$ with the exception of Ouara basin (0.34). On the other hand, low Hurst exponents are found in the Kasaï $(0.39-0.47)$ and the southern coastal $(0.23-0.40)$ domains. Relief at the scale of $10 \mathrm{~km}$ is generally more important for the East African rift $\left(R_{0}=100-120 \mathrm{~m}\right)$ than for the Kasai and coastal bulge $\left(\mathrm{R}_{0}=70-90 \mathrm{~m}\right)$, or the northern part of the Congo drainage basin $\left(\mathrm{R}_{0}=50-60 \mathrm{~m}\right)$.

\subsubsection{Summary}

[27] The three retained morphometric parameters allow identification of four regional trends in the Congo River drainage basins: (1) mature drainage basins in the Eastern part (concave longitudinal profiles, concave hypsometric curves, and smooth relief); (2) poorly mature basins in the northwestern part (convex longitudinal profiles, convex 

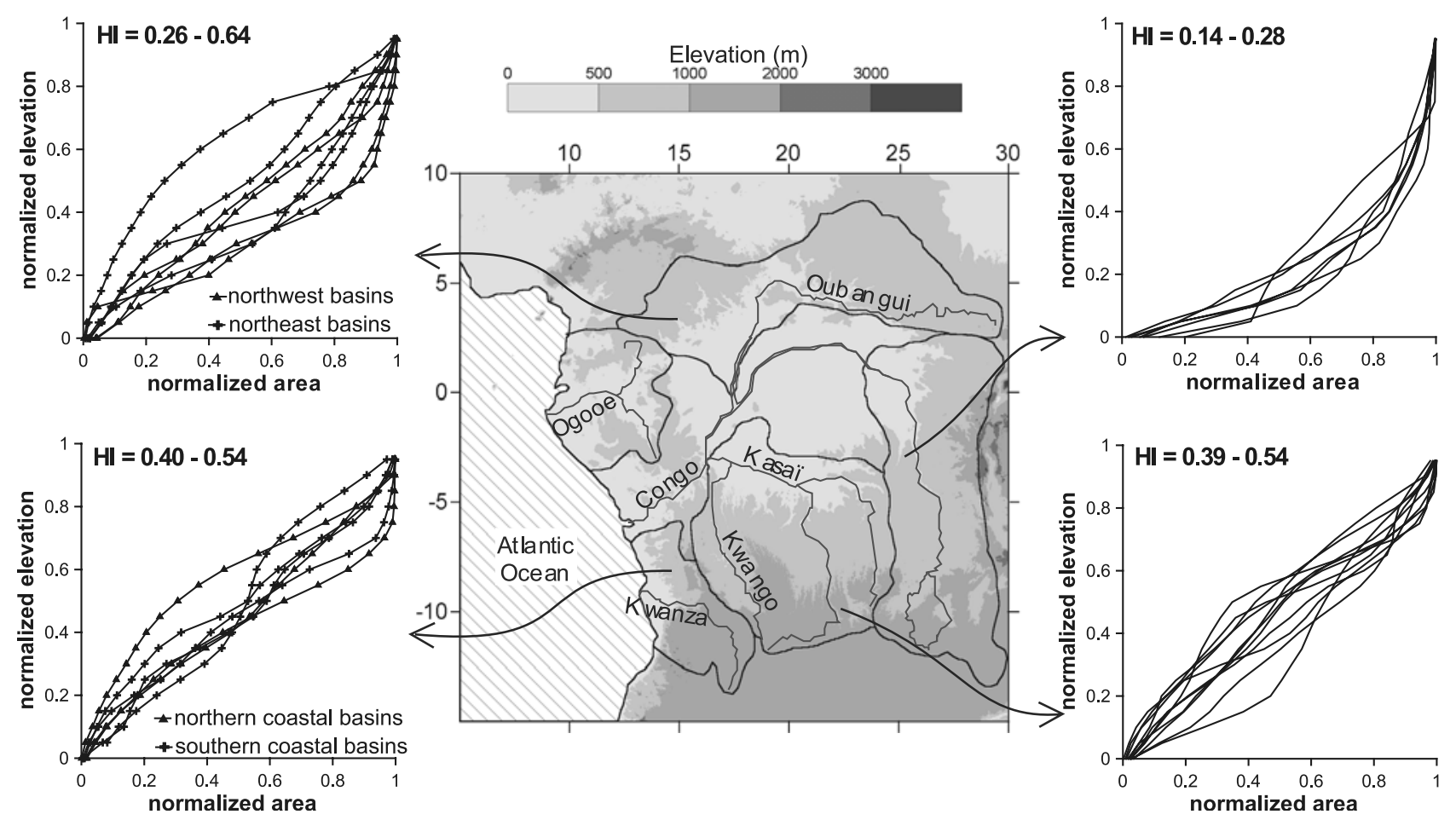

Figure 9. Hypsometric analysis of selected subbasins (hypsometric curves and hypsometric integrals HI). Hypsometric parameters show a regional distribution with both mature drainage basins (low HI and concave curves) along the East African Rift flank and immature drainage basins (high $\mathrm{HI}$ and convex curves) to the south. To the north, hypsometric parameters also show both immature drainage basins (linked with the presence of a $610 \mathrm{~m}$ plateau located in the central part of the Congo basin) and mature drainage basins.

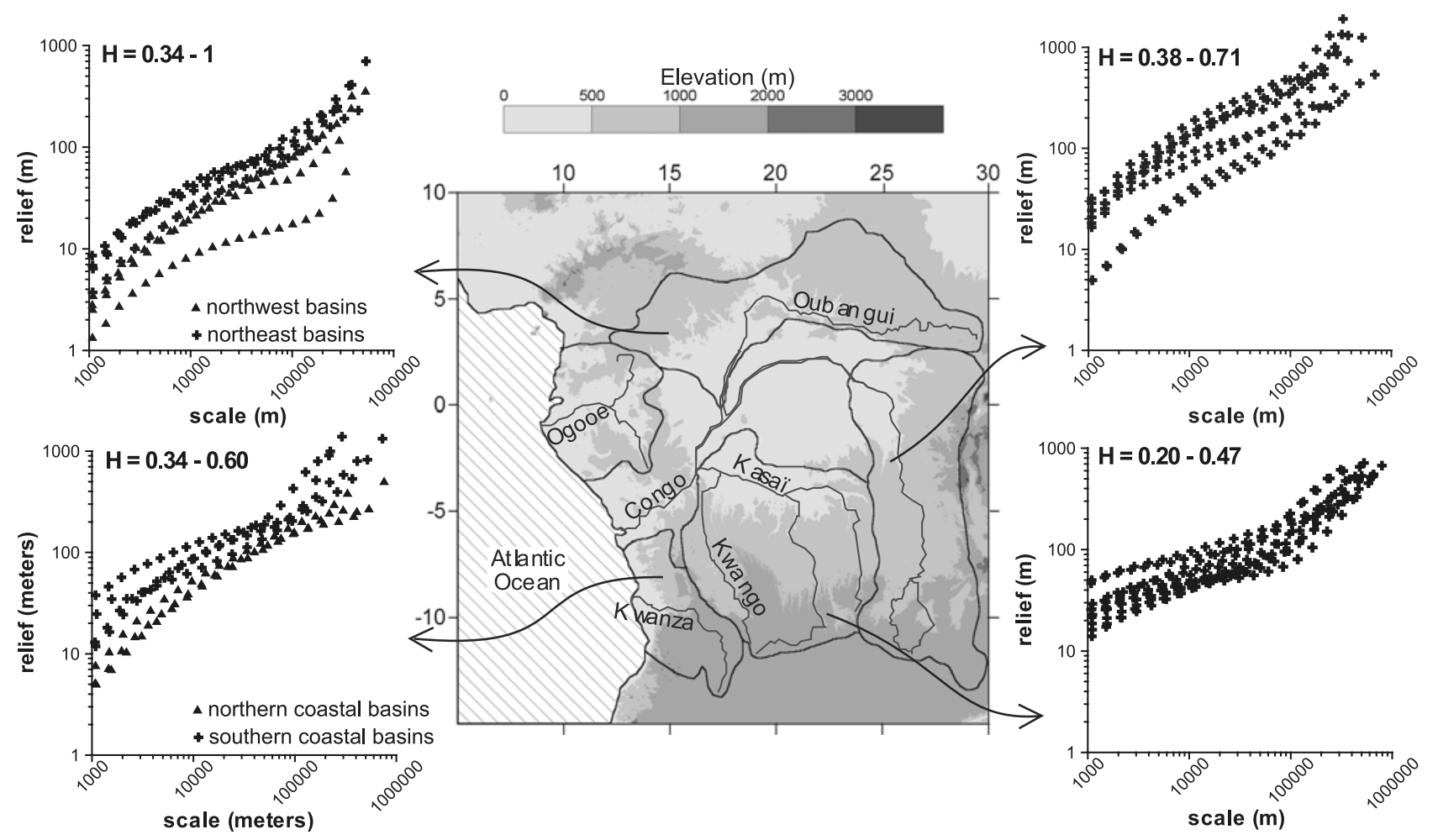

Figure 10. Length scale analysis of relief properties of selected subbasins (H, Hurst exponent). Relief properties show a similar regional trend as hypsometric parameters. Low Hurst exponents are found to the south (Kasaï area and southern coastal domain), and high Hurst exponents are found in the north and along the East African Rift flank. 
hypsometric curves); (3) highly immature drainage basins in the Southern part and along the coastal bulge ( $\mathrm{S}$ shape longitudinal profiles, convex hypsometric curves and rough relief); and (4) immature basins (sigmoid hypsometric curves, variable Hurst exponents) related to the presence of the $610 \mathrm{~m}$ high plateau. A large domain of the Congo basin is therefore immature, showing that uplift has been recent or erosion weak.

\section{Discussion}

[28] The present-day sediment discharge of the Congo River is consistent with our total denudation estimate of 725,000 to $1 \times 10^{6} \mathrm{~km}^{3}$ : extrapolation from Oligocene (35 Ma) of the Gaillardet et al. [1995] results (6 m/Myr or $2.1 \times 10^{4} \mathrm{~km}^{3} / \mathrm{Myr}$ ) leads to an average denudation of $210 \mathrm{~m}$ and a total volume of $735,000 \mathrm{~km}^{3}$. In addition, both methods attribute to the East African Rift and the Kasai domains the most important role for the Congo River solid load.

[29] The total denudation may have been underestimated by some changes of the drainage basin limits or significant erosion of the divides in domains where no remnant surface exists. It is unlikely that more denudation came from the Kasai domain, because of the highly immature character of basins. This excludes the possibility that a spreader drainage has ever extended to the south (Namibia) where Gallagher and Brown [1999] have noticed local Tertiary denudation. In the East, evolution of the African rift in two branches may have decreased the drainage area during Tertiary: Zeyen et al. [1997] proposed a model of the East African Rift in which the Tanzanian Craton is tilted to the west by a rising plume in the Early Oligocene. A consequence of this model is that the Congo drainage area increases by $1 \times 10^{6} \mathrm{~km}^{2}$ (area between the two rift branches) until the development of the western branch of the rift around $12 \mathrm{Ma}$. This scenario allows adding $230,000-300,000 \mathrm{~km}^{3}$ to the total denudation within the present Congo River drainage basin, assuming the same average denudation as that of the western flank (230-310 m) and better explains the onset of high sedimentation rates during early Oligocene in the Gulf of Guinea. Contribution of coastal rivers may have been neglected as extrapolation of remnant surface is difficult and that Oligocene and Miocene erosion stages are identified on proximal margin: thermochronological data on the Angola platform suggest denudation thickness as high as $2 \mathrm{~km}$ [Walgenwitz et al., 1990].

[30] The volume of sediment deposited in the Gulf of Guinea on the other hand is 1.2 to $1.5 \times 10^{6} \mathrm{~km}^{3}$. This is the order of magnitude of the erosion in the Congo River drainage basin with the addition of coastal rivers' contribution. A progressive increase of sediment flux is however observed in the Congo fan showing an acceleration of denudation with time.

[31] During late Cretaceous and Paleocene, the location of depot centers is different and corresponds essentially to the Ogooe and Kwanza fans. Another million cubic kilometers has been eroded at that time, but it is unlikely that an important proportion comes from the present Congo drainage basin because of the presence of remnant surfaces. However, the more likely place for Cretaceous denudation may be the Central African Rift System (CARS), in the northern part of the Congo River drainage basin. Genik [1992] and Guiraud and Bosworth [1997] have shown that the northern border of the Congo drainage basin was inverted during late Santonian. Remnant surfaces are not present in this region, showing that former fold and thrust belt topography has possibly been eroded. An older connection between Oubangui River and Ogooe River may have existed providing the necessary material to feed the upper Cretaceous fan in Gabon margin. A similar source of sediment is necessary for the Kwanza fan, and one should assume that the paleo-Kwanza basin was more developed with possible connections with Zambeze or Okavongo drainage.

[32] Morphometric analysis of the large-scale topography in the Congo River drainage basin can provide a relative timescale of erosion processes. The Western branch of the East African Rift that starts around 12-13 Ma [Ebinger, 1989] has the highest elevation but the smoothest relief and the more mature hypsometry. The northern part of the Kalahari plateau, probably related to an African superswell supported dynamically [Nyblade and Robinson, 1994; Lithgow-Bertelloni and Silver, 1998], has been eroded by a system of very immature drainage basins (Kasaï tributaries). Assuming that all other factors do not affect the erosion pattern all around the Congo River drainage basin, the comparison with the maturity of the East African Rift basins suggest that uplift of the Kalahari plateau is not older than $10 \mathrm{Ma}$. A similar argument can be used for the development of the $610 \mathrm{~m}$ plateau all around the Congo basin. Basins that develop on this plateau are very immature, mostly on the Eastern part. A relationship with a necessary uplift of $500 \mathrm{~m}$ on the proximal margin of the Gulf of Guinea [Lavier et al., 2001] is likely [Lucazeau et al., 2003].

[33] On the basis of sediment rates calculated along two profiles across the Congo fan, Lavier et al. [2001] proposed that the change in sediment supply correlates with a global cooling of climatic conditions in the southern hemisphere characterized by ice accumulation in Antarctica [Barron et al., 1991; Wise et al., 1992] and increase in continent/ocean temperature contrasts [Séranne, 1999]. Therefore they suggest that the onset of high sedimentation rates on the margin is linked with this climatic event. On the other hand, on the southwestern margin of Africa (i.e., south of the Walvis Ridge), Rust and Summerfield [1990] found that sediment accumulation decreases by half at the transition Eocene/Oligocene. Similarly, Ogooe and Kwanza sedimentation decreases at the same time. The Mozambique margin evolves the same way [Davies et al., 1995; Salman and Abdula, 1995]. Our interpretation is that sediment discharge following the Atlantic breakup has been more controlled by the reorganization of drainage in connection with the different vertical movements rather than global climatic changes. The youth of morphology and the increase of sediment flux in the Congo fan suggest a recent development of surrection.

[34] Acknowledgments. This work has been funded by a TFE research project ("Deepwater R\&D Project") through a visiting grant for F.L. and a postdoc grant for P.L. The Cretaceous and Tertiary isopach maps are derived from the TFE synthesis by P. Unternehr and H. Pigeyre. The authors want to thanks TFE for providing some of the data and for authorizing publication. We also thank the reviewers J. Milliman and 
J. Friedmann, for their constructive remarks for improving the manuscript. IPGP contribution 1908.

\section{References}

Anhert, F., Functional relationships between denudation, relief and uplift in large mid latitude drainage basins, Am. J. Sci., 268, 243-263, 1970.

Band, L. E., Topographic partition of watersheds within digital elevation models, Water Resour. Res., 22, 15-24, 1986.

Barron, J., B. Larsen, and J. G. Baldauf, Evidence for late Eocene to early Oligocene Antartic glaciation and observations on late Neogene glacial history of Antarctica: Results form Leg 119, Proc. Ocean Drill. Program Sci. Results, 119, 869-891, 1991.

Brognon, G., The geology of the Angola coast and continental margin, in The Geology of the East Atlantic Continental Margin, edited by F. M. Delany, Rep. 70/13, pp. 143-152, Inst. of Geol. Sci., London, 1971.

Burollet, P. F., Tectonique en radeaux en Angola, Bull. Soc. Géol. Fr., 22, 503-504, 1975.

Davies, T. A., R. B. Kidd, and A. T. Ramsay, A time-slice approach to the history of Cenozoic sedimentation in the Indian Ocean, Sediment. Geol., 96, 157-179, 1995.

Ebinger, C. J., Tectonic development of the western branch of the East African Rift System, Geol. Soc. Am. Bull., 101, 885-903, 1989.

Emery, K. O., E. Uchupi, J. Phillips, C. Bowin, and J. Mascle, Continental margin off western Africa: Angola to Sierra Leone, AAPG Bull., 59 , 2209-2265, 1975.

Foster, D., and A. Gleadow, Structural framework and denudation history of the flanks of the Kenya and Anza Rifts, East Africa, Tectonics, 15, $258-$ 271, 1996.

Gaillardet, J., B. Dupré, and C. J. Allègre, A global Chemical budget applied to the Congo basin rivers: Erosion rates and continental crust composition, Geochim. Cosmochim. Acta, 59, 3469-3485, 1995.

Gallagher, K., and R. Brown, The Mesozoic denudation history of the Atlantic margins of southern Africa and southeast Brazil, and the relationship to offshore sedimentation, in The Oil and Gas Habitats of the South Atlantic, edited by N. R. Cameron, R. H. Bate, and V. S. Clure, Geol. Soc. Spec. Publ., 153, 41-53, 1999.

Genik, G. J., Regional framework, structural and petroleum aspects of rift basins in Niger, Chad and the Central African Republic (C.A.R.), Tectonophysics, 213, 169-185, 1992.

Goodrich, H. B., Geology of the Yukon Gold District, Alaska, United States, annual report, Geol. Soc., Washington, D. C., 1898.

Guiraud, R., and W. Bosworth, Senonian basin inversion and rejuvenation of rifting in Africa and Arabia: Synthesis and implications to plate-scale tectonics, Tectonophysics, 282, 39-82, 1997.

Holbrook, J., and S. A. Schumm, Geomorphic and sedimentary response of rivers to tectonic deformation: A brief review and critique of a tool for recognizing subtle epeirogenic deformation in modern and ancient settings, Tectonophysics, 305, 287-306, 1999.

Howard, A. D., Drainage analysis in geological interpretation: A summary, AAPG Bull., 51, 2246-2259, 1967.

Hurtrez, J. E., and F. Lucazeau, Lithologic control on relief and hypsometry in the Hérault drainage basin (France), C. R. Acad. Sci., 328(10), 687$694,1999$.

Hurtrez, J. E., F. Lucazeau, J. Lavé, and J. P. Avouac, Investigation of the relationships between basin morphology, tectonic uplift and denudation from the study of an active fold belt in the Siwalik hills (central Nepal), J. Geophys. Res., 104, 12,779-12,796, 1999a.

Hurtrez, J. E., C. Sol, and F. Lucazeau, Effect of drainage area on hypsometry from an analysis of small scale drainage basins in the Siwalik hills (Central Nepal), Earth Surf. Processes Landforms, 24, 799-808, 1999b.

Lavier, L. L., M. S. Steckler, and F. Brigaud, Climatic and tectonic control on Cenozoic evolution of the West African margin, Mar. Geol., 178, 6380, 2001.

Lawrence, S. R., and M. M. Makazu, Zaire's central basin: Prospectivity outlook, Oil Gas J., 86(38), 105-108, 1988.

Lifton, N. A., and C. G. Chase, Tectonic, climatic and lithologic influences on landscape fractal dimension and hypsometry: Implications for landscape evolution in the San Gabriel Mountains, California, Geomorphology, 5, 77-114, 1992.

Lithgow-Bertelloni, C., and P. G. Silver, Dynamic topography plate driving forces and the African superswell, Nature, 395, 269-272, 1998.

Lucazeau, F., and J. E. Hurtrez, Length scale dependence of relief along the south eastern border of Massif Central (France), Geophys. Res. Lett., 24(14), 1823-1826, 1997.

Ludin, E. R., Thin-skinned extensional tectonics on a salt detachment, northern Kwanza Basin, Angola, Mar. Pet. Geol., 9, 405-411, 1992.

Marton, L. G., G. C. Tari, and C. T. Lehman, Evolution of the Angolan Passive Margin, West Africa, with the emphasis on post-salt structural styles, in Atlantic Rifts and Continental Margins, Geophys. Monogr. Ser., vol. 115, edited by W. Mohriak and M. Talwani, pp. 129-149, AGU, Washington, D. C., 2000.

Masek, J. G., B. L. Isacks, T. L. Gubbels, and E. J. Fielding, Erosion and tectonics at the margins of continental plateaus, J. Geophys. Res., 99, 13,941-13,956, 1994.

Mauduit, T., and J. P. Brun, Growth fault/rollover systems: Birth, growth and decay, J. Geophys. Res., 103, 18,119-18,136, 1998.

McGinnis, J. P., N. W. Driscoll, G. D. Karner, W. D. Brumbaugh, and N. R. Cameron, Flexural response of passive margins to deep sea erosion and slope retreat: Implications for the relative sea-level change, Geology, 21, $893-896,1993$

Meade, R. H., T. Dunne, J. E. Richey, U. M. Santos, and E. Salati, Storage and remobilization of suspended sediments in the lower Amazon river of Brazil, Science, 228, 488-490, 1985.

Merrits, D. J., K. R. Vincent, and E. E. Wohl, Long river profiles, tectonism, and eustasy: A guide to interpreting fluvial terraces, J. Geophys. Res., 99, 14,031-14,050, 1994.

Métivier, F., Y. Gaudemer, and M. Klein, Mass accumulation rates in Asia during the Cenozoic, Geophys. J. Int., 137, 280-318, 1999.

Milliman, J. D., and J. P. M. Syvitski, Geomorphic/tectonic control of sediment discharge to the ocean: The importance of small mountainous rivers, J. Geol., 100, 525-544, 1992.

Moussa, R., Variation spatio-temporelle et modélisation hydrologique: Application au bassin du Gardon d'Anduze, thesis, Univ. Montpellier 2, Montpellier, France, 1991.

Moussa, R., M. G. Tournoud, and C. Bocquillon, Extraction and analysis of the structure of drainage network from digital elevation models, in Computer Methods and Water Resources IV, edited by Y. Abousleiman, C. A. Brebbia, and A. H. D. Cheng, WIT Press, Southampton, U.K., 1999.

Noble, W., D. Foster, and A. Gleadow, The post-Pan-African and extensional history of crystalline basement rocks in eastern Tanzania, Tectonophysics, 275, 331-350, 1997.

Nürnberg, D., and R. D. Mueller, The tectonic evolution of the South Atlantic from late Jurassic to present, Tectonophysics, 191, 27-53, 1991.

Nyblade, A. A., and S. W. Robinson, The African superswell, Geophys. Res. Lett., 21, 765-768, 1994.

Ohmori, H., Changes in the hypsometric curve through mountain building resulting from concurrent tectonics and denudation, Geomorphology, 8 , 263-277, 1993.

Ouchi, S., Response of alluvial rivers to slow active tectonic movement, Geol. Soc. Am. Bull., 96, 504-515, 1985.

Pinet, P., and M. Souriau, Continental erosion and large-scale relief, Tectonics, 7, 563-582, 1988.

Rasmussen, E. S., Structural evolution and sequence formation offfshore South Gabon during Tertiary, Tectonophysics, 266, 509-523, 1996.

Roessner, S., and M. R. Strecker, Late Cenozoic tectonics and denudation in the central Kenya Rift; quantification of long-term denudation rates, Tectonophysics, 278, 83-94, 1997.

Rust, D. J., and M. A. Summerfield, Isopach and borehole data as indicators of rifted margin evolution in southwestern Africa, Mar. Pet. Geol., 7, 277-287, 1990

Sahagian, D. L., Epeirogenic motions of Africa as inferred from Cretaceous shoreline deposits, Tectonics, 7, 125-138, 1988.

Salman, G., and I. Abdula, Development of the Mozambique and Ruvuma sedimentary basins, offshore Mozambique, Sediment. Geol., 96, 7-41, 1995.

Savoye, B., et al., Structure et evolution recente de l'eventail turbiditique du Zaire; premiers resultats scientifiques des missions d'exploration Zaiango 1 \& 2(marge Congo-Angola), C. R. Acad. Sci., Sér. II, 331(3), 211-220, 2000 .

Séranne, M., Early Oligocene stratigraphi turnover on the west Africa continental margin: A signature of the Tertiary greenhouse-to-icehouse conditions, Terra Nova, 11, 135-140, 1999.

Séranne, M., M. Seguret, and M. Fauchier, Seismic super-units and post-rift evolution of the continental passive margin of southern Gabon, Bull. Soc. Géol. Fr., 163, 135-146, 1992.

Sklar, L., and W. E. Dietrich, River longitudinal profiles and bedrock incision models: Stream power and the influence of sediment supply, in Rivers Over Rock: Fluvial Processes in Bedrock Channels, Geophys. Monogr. Ser., vol. 107, edited by K. J. Tinkler and E. E. Wohl, pp. 237-260, AGU, Washington, D. C., 1998.

Strahler, A. N., Hypsometric (area-altitude) analysis of erosional topography, Geol. Soc. Am. Bull., 63, 1117-1141, 1952.

Uenzelmann-Neben, G., Neogene sedimentation history of the Congo fan, Mar. Pet. Geol., 15, 635-650, 1998.

U.S. Geological Survey, Earth Resources Data Center (USGS-EDC), Global 30 -arc second elevation data set (GTOPO30), Sioux Falls, S. D., 1996. (Available at the http://edcdaac.usgs.gov/gtopo30/README. html) 
Valle, P. J., J. G. Gjelberg, and W. Helland-Hansen, Tectonostratigraphic development in the eastern Lower Congo Basin, offshore Angola, West Africa, Mar. Pet. Geol., 18, 909-927, 2001.

Van den Haute, P., Fission track ages of apatites from the Precambrain of Rwanda and Burundi: Relationship to East African Rift tectonics, Earth Planet. Sci. Lett., 71, 129-140, 1984.

Van der Beek, P. A., and J. Braun, Numerical modeling of landscape evolution on geological time scales: A parameters analysis and comparison with the south-eastern highlands of Australia, Basin Res., 10, 49-68, 1998.

Van der Beek, P. A., E. Mbede, P. Andrienssen, and D. Delvaux, Denudation history of the Malawi and Rukwa Rift flanks (East African Rift System) from apatite fission track thermochronology, J. Afr. Earth Sci., 26, 363-385, 1998.

Vörösmarty, C. J., B. M. Fekete, M. Meybeck, and R. B. Lammers, Geomorphometric attributes of the global systeme of rivers at $30^{\prime \prime}$ spatial resolution, J. Hydrol., 237, 17-39, 2001.

Walgenwitz, F., M. Pagel, A. Meyer, H. Maluski, and P. Monié, Thermochronological approach to reservoir diagenesis in the offshore Angola basin: A fluid inclusion, ${ }^{40} \mathrm{Ar}^{39}{ }^{39} \mathrm{Ar}$ and $\mathrm{K}-\mathrm{Ar}$ investigation, $A A P G$ Bull., 74, 547-563, 1990.

Weissel, J. K., L. F. Parsons, and A. Malinverno, The length-scaling properties of topography, J. Geophys. Res., 99, 13,997-14,012, 1994.

Weissel, J. K., A. Malinverno, D. J. Harding, and G. D. Karner, Erosional development of the Etiopian plateau of northeast Africa from a fractal analysis of topography, in Fractals in Petroleum Geology and Earth Processes, edited by C. C. Barton and P. R. LaPointe, pp. 127-142, Plenum, New York, 1995.

Whipple, K. X., and G. E. Tucker, Dynamics of the stream-power river incision for height limits of mountain ranges, landscape response timescales, and research model, J. Geophys. Res., 104, 17,661-17,674, 1999.

Wise, S. W., J. R. Breza, D. M. Harwood, W. Wei, and J. C. Zachos, Paleogene glacial history of Antartica in light of leg 120 drilling results, Proc. Ocean Drill. Program Sci. Results, 120, 1001-1030, 1992.

Zeyen, H., F. Volker, V. Werhle, K. Fuchs, S. V. Sobolev, and R. Altherr, Styles of continental rifting: Crust-mantle detachment and mantle plumes, Tectonophysics, 278, 329-352, 1997.

F. Brigaud, FinnestadVeien 44, Dusavik, P.O. Box 168, N-4001 Stavanger, Norway. (frederic.brigaud@ep.total.no)

P. Leturmy, Département des Sciences de la Terre, Univ. é de CergyPontoise, F-95031 Cergy-Pontoise Cedex, France. (Pascale.Leturmy@geol. u-cergy.fr)

F. Lucazeau, Laboratoire Géosciences Marines, Institut de Physique du Globe, 4, place Jussieu, F-75252 Paris cedex 05, France. (lucazeau@ipgp. jussieu.fr) 